\title{
Irrigation with saline-sodic water: Effects on soil chemical-physical properties
}

\author{
G. Cucci, G. Lacolla and P. Rubino \\ Department of Agricultural and Environmental Science, University of Bari Via G. Amendola 165/A 70126 Bari, Italy.
}

Accepted 26 September, 2011

\begin{abstract}
The results of a two-year research, aimed at studying the effect of irrigation with saline and sodic water on soil physical and chemical properties, are reported. Bean and capsicum were grown in pots filled with two different clay-loam soils, irrigated with 9 types of water obtained from the factorial combination of three salt concentration levels $(0.001-0.01-0.1 \mathrm{M}$ for bean, and 0.01-0.032- $0.1 \mathrm{M}$ for capsicum) with three sodium adsorption ratio (SAR) levels $(5,15$ and 45$)$ and were subjected to two leaching fractions (10 and $20 \%$ ). The results did not show any significant effect of irrigation water's salinity and sodicity, and of the leaching fraction, on soil type. The use of irrigation water with $0.1 \mathrm{M}$ salt concentration caused an increase in electrical conductivity (ECe) from an initial average value of 0.71 dS $\mathrm{m}^{-1}$ to 13.9 and $19.5 \mathrm{dS} \mathrm{m}^{-1}$, at the end of the first and the second irrigation season, respectively; small variations were, instead, observed, for soil $\mathrm{pH}$. Despite the use of leaching fractions, any increase in the salt concentration and SAR of irrigation water resulted in an increase in the exchangeable $\mathrm{Na}$ percentage and a decrease in the exchangeable $\mathrm{K}, \mathrm{Ca}$ and $\mathrm{Mg}$.
\end{abstract}

Key words: Soil type, sodic-saline water, leaching, exchangeable sodium percent (ESP), soil aggregates stability.

\section{INTRODUCTION}

Soil salinization and sodification have been identified as major causes of land degradation. Postel (1996) reports that salt-affected areas increase at a high rate, by about 2 million hectares per year. Secondary salinization is the consequence of a not optimal irrigation water management and of the use of saline water for irrigation. This problem is particularly critical in arid and semi-arid regions where total water availability is limited and good quality water is addressed to high-valued uses, and thus poor quality waters, including wastewaters (Minhas et al., 2007; UNESCO, 2003), is often used for irrigation (Richards et al., 1954; Szabolcs, 1989; So and Aylmore, 1993; Tedeschi and Dell'Aquila, 2005). Particularly, if this concerns domestic wastewater, it may have high $\mathrm{Na}$ concentrations resulting from the salt content of human

*Corresponding author. E-mail: giovanna.cucci@agr.uniba.it. Tel: +39080 5443005. Fax: +390805442976. food (Tedeschi and Menenti, 2002; van der Zee et al., 2010).

The problems related to the use of highly saline water affect above all the desert areas in Southern America; some states of the U.S.A: such as California, Arizona (Ayers and Westcot, 1985); many Asian regions, including Pakistan, India, Bangladesh, China, Japan (Levy et al., 1988); the Middle East, the areas between Tigris and Euphrates (Iraq), Bahrain (Ayers and Westcot, 1985); the Negev Desert (Israele) (Pasternak and De Malach, 1987) and the Mediterranean region (Levy et al., 1988). The problem does also exist in Italy, especially in CentralSouthern areas, where groundwater is the main source of water supply. As a consequence of the water table drawdown, caused both by its continuous and intensive exploitation and by the low rainfall recorded over the last decades, a significant increase in the salt content of water occurs especially in coastal areas, thus causing a further deterioration of the existing conditions (Graifenberg et al., 1993; Postiglione et al., 1994). 
The major problem of irrigating with saline water is not actually the crop response to irrigation (which is a basically short-term effect) but rather the long-term changes on soil properties that might seriously alter its fertility.

The risk of soil fertility degradation depends both on the total salt content of irrigation water and on the salt composition, especially in relation to $\mathrm{Na}$ concentration.

Soil sodification refers to the accumulation of $\mathrm{Na}$, in relation to divalent cations (mainly $\mathrm{Ca}$ and $\mathrm{Mg}$ ), in the soil solution and at the cation exchange complex and may induce severe structural degradation in loamy and clayey soils that contain swelling minerals (Bresler et al., 1982), as consequence of clay particle dispersion. Among physical parameters, the soil aggregates stability index can be considered a good indicator of the soil quality status as function of the agronomic practices adopted (Manachini et al., 2009). Soil fertility degradation depends on irrigation water quality and on soil physical properties as well, with particular regard to clay mineral characteristics (Cavazza et al., 2002).

The de-flocculating effect of sodium ion on clay increases with the concentration of adsorbed sodium; the critical level of exchangeable sodium percentage (ESP) is usually taken as $15 \%$ of the cation exchange capacity, although in some soils the sodification characteristics occur at much lower values (Murray and Quirk, 1990).

If ESP becomes too large (e.g. over 15\%), the hazard of organic and inorganic colloid dispersion upon introducing good quality water (such as rainwater) increases. Swelling, compression of larger pores, and a severe and often irreversible reduction of hydraulic conductivity can be the result (So and Aylmore, 1993; Halliwell et al., 2001). Since the development of soil sodicity is gradual, and often irreversible within limits imposed by reasonable time scales and costs, it is essential to anticipate its onset. Unfortunately, relatively simple conceptual tools such as the leaching requirement for salinity control (Richards et al., 1954; Howell, 1988; Corwin et al., 2007) are not available for sodicity control. The analysis of the evolution of soil chemical and physical properties, as consequence of supplying water characterized by different total salt concentrations and type, could aid to a better understanding of processes involved and to the definition of tools and land managements able to reduce the soil degradation risk.

Therefore, to provide additional insight into this issue, a two-year research has been performed at Bari University (Italy) with the aim of assessing the effects of irrigation with saline and sodic water on physical and chemical properties of two contrasting soils.

\section{MATERIALS AND METHODS}

The research was carried two-year period at the Campus of the Agricultural Faculty of Bari University (Italy) on bean (Phaseolus vulgaris L.) and capsicum (Capsicum annuum L.) successive crops, grown in cylindrical pots of 20 and $100 \mathrm{~cm}$ respectively in diameter and height, supplied with a bottom valve to collect drained water, and located under shed to prevent the leaching action of rainfall.

In both years, thirty-six treatments obtained from the factorial combination of two not saline soil types with nine types of water and two leaching fractions (10 to $20 \%$ ) were compared.

The soils were clay loam; the first (T1) was poor in iron and aluminium sesquioxides, non calcareous, taken from the AP horizon of a Udertic Ustochrept fine, mixed mesic, series Montefalcone on the Emilia-Romagna soil map, northern Italy; the second (T2) contained more kaolin, it was calcareous and rich in sesquioxides, taken from the AP horizon of a Pachic Haploxeroll, fine mixed, thermic, series Cutino on the Apulia soil map, southern Italyn (Table 1).

The nine types of water were obtained by dissolving adequate amounts of $\mathrm{NaCl}$ and $\mathrm{CaCl}_{2}$ in de-ionised water, and from the factorial combination of three salt concentration levels $(0.001-0.01$ $-0.1 \mathrm{M}$ for bean irrigation in the first year; $0.01-0.032-0.1 \mathrm{M}$ for capsicum irrigation in the second year) with 3 SAR (sodium adsorption ratio) levels (5 - 15 - 45) (Table 2$)$.

A split plot design with two replicates was used, with the two soil types in plots (18 pots), the two leaching fractions in sub-plots ( 9 pots) and the nine types of water in sub-sub-plots (single pots). As concerns, the fat round bean, cv. Taylor's Horticultural, just after sowing several water applications were effected using the compared different types of water to favour seed germination and plantlet emergence, which occurred 15 to 20 days after sowing. For capsicum (cv. Argo) just after transplantation, plantlets were instead irrigated with de-ionised water till rooting. Just after bean emergence and capsicum plantlet rooting, irrigation was applied whenever $30 \%$ of the maximum available moisture was lost by evapotranspiration. The amount of irrigation water corresponded to the volume required to restore the field capacity in the whole soil mass contained in each pot, plus the leaching fraction.

Through the cropping cycles, the water drained from each pot was collected and analysed for the leached solutes.

To characterise the soil at the end of the cropping cycle both for fat round bean and capsicum, for each pot (when it had lost $30 \%$ of the maximum available moisture) soil samples were taken from the upper layer $(0$ to $30 \mathrm{~cm})$ for the following determinations:

1. Electrical conductivity and $\mathrm{pH}$ of the saturation extract, soluble bases ( $\mathrm{Na}, \mathrm{Ca}, \mathrm{Mg})$, SAR;

2. Exchangeable cations ( $\mathrm{Na}-\mathrm{K}-\mathrm{Ca}-\mathrm{Mg}$ ), exchangeable sodium percentage.

After the two years of irrigation with saline-sodic waters, the soil stability has been evaluated on average samples collected along the whole profile, after separating the soil aggregates ranging between 1 and $2 \mathrm{~mm}$ diameter and using wet sieving with vertical oscillation, with or without alcohol pretreatment (Hénin et al., 1969; Kemper and Rosenau, 1986). The tests of stability of the aggregates allow differentiating soils according to their physical properties, but little is known about the relationship between indicators of aggregate stability and soil response to specific destabilizing factors.

All data were then submitted to analysis of variance using the SAS software (S.A.S.INSTITUTEINC.-USA), and the differences between the means were assessed by the Student-Newman-Keuls test; the most significant ones are reported in Figures 1 to 7 .

\section{RESULTS}

In the adopted watering regime, the irrigation variables were equal for both soil types being compared but varied 
Table 1. Main properties of the soils being tested.

\begin{tabular}{|c|c|c|}
\hline Parameter & T1 & T2 \\
\hline \multicolumn{3}{|l|}{ Chemical properties } \\
\hline Total nitrogen (Kjeldahl method) $\left(\mathrm{g} \mathrm{kg}^{-1}\right)$ & 0.79 & 1.65 \\
\hline Available phosphorus (Olsen method) ( $\mathrm{mg} \mathrm{kg}^{-1}$ ) & 31.50 & 52.50 \\
\hline Exchangeable potassium $\left(\mathrm{BaCl}_{2}\right.$ method) $\left(\mathrm{mg} \mathrm{kg}^{-1}\right)$ & 160.00 & 352.00 \\
\hline 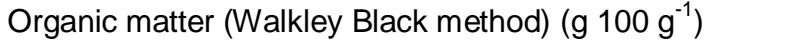 & 1.21 & 3.13 \\
\hline 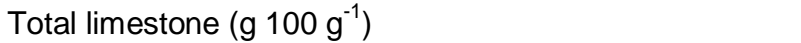 & 0.47 & 2.58 \\
\hline Active limestone $\left(\mathrm{g} 100 \mathrm{~g}^{-1}\right)$ & 0.05 & 1.40 \\
\hline $\mathrm{pH}\left(\mathrm{pH}\right.$ in $\left.\mathrm{H}_{2} \mathrm{O}\right)$ & 6.80 & 6.90 \\
\hline $\mathrm{ECe}\left(\mathrm{dS} \mathrm{m} \mathrm{m}^{-1}\right)$ & 0.65 & 0.78 \\
\hline ESP & 0.70 & 0.80 \\
\hline CEC ( $\mathrm{BaCl}_{2}$ method) (meq $100 \mathrm{~g}^{-1}$ of dry soil) & 29.54 & 31.61 \\
\hline \multicolumn{3}{|l|}{ Particle-size analysis } \\
\hline Total sand: $2>\varnothing>0.02 \mathrm{~mm}\left(\mathrm{~g} 100 \mathrm{~g}^{-1}\right)$ & 30.27 & 20.94 \\
\hline Silt (\%): $0.02>\varnothing>0.002 \mathrm{~mm}\left(\mathrm{~g} 100 \mathrm{~g}^{-1}\right)$ & 33.10 & 44.00 \\
\hline Clay $(\%): \varnothing<0.002 \mathrm{~mm}\left(\mathrm{~g} 100 \mathrm{~g}^{-1}\right)$ & 33.63 & 35.06 \\
\hline \multicolumn{3}{|l|}{ Hydrologic properties } \\
\hline Field capacity (field determ.) ( $\left(100 \mathrm{~g}^{-1}\right.$ of soil dry mass ) & 34.50 & 35.80 \\
\hline Wilting point (-1.5 MPa) (g $100 \mathrm{~g}^{-1}$ of soil dry mass ) & 14.70 & 18.40 \\
\hline Bulk density $\left(\mathrm{t} \mathrm{m}^{-3}\right)$ & 1.20 & 1.20 \\
\hline
\end{tabular}

Table 2. Salt concentration, sodium adsorption ratio (SAR) and electrical conductivity (ECw) of the irrigation water compared.

\begin{tabular}{|c|c|c|c|c|c|}
\hline \multicolumn{3}{|c|}{ Bean } & \multicolumn{3}{|c|}{ Capsicum } \\
\hline $\begin{array}{l}\text { Salt concentration } \\
\text { (M) }\end{array}$ & SAR & $\begin{array}{c}E C w \\
\left(\mathrm{dS} \mathrm{m}^{-1}\right)\end{array}$ & $\begin{array}{l}\text { Salt concentration } \\
\text { (M) }\end{array}$ & SAR & $\begin{array}{c}E C w \\
\left(d S m^{-1}\right)\end{array}$ \\
\hline 0.001 & 5 & 0.13 & 0.01 & 5 & 1.47 \\
\hline 0.001 & 15 & 0.12 & 0.01 & 15 & 1.24 \\
\hline 0.001 & 45 & 0.12 & 0.01 & 45 & 1.19 \\
\hline 0.01 & 5 & 1.47 & 0.032 & 5 & 4.65 \\
\hline 0.01 & 15 & 1.24 & 0.032 & 15 & 3.86 \\
\hline 0.01 & 45 & 1.19 & 0.032 & 45 & 3.59 \\
\hline 0.1 & 5 & 13.55 & 0.1 & 5 & 13.55 \\
\hline 0.1 & 15 & 11.18 & 0.1 & 15 & 11.18 \\
\hline 0.1 & 45 & 10.20 & 0.1 & 45 & 10.20 \\
\hline
\end{tabular}

according to the quality of applied water. The number of waterings and the seasonal irrigation volumes supplied to each pot based on evapotranspiration, decreased as the irrigation water salinity and SAR increased, due to the smaller plant development. On average, the seasonal irrigation volumes per pot decreased as the salt concentration of the irrigation water increased, respectively with leaching fractions of 10 and $20 \%$ of the watering volume, from 35 to $13 \mathrm{~L}$ and from 40 to $16 \mathrm{~L}$ for bean, from 67 to $56 \mathrm{~L}$ and from 75 to $64 \mathrm{~L}$ for capsicum. Even the solutes supplied to each pot varied as a function of the quality and quantity of applied water (Figure 1).

In particular, with $10 \%$ leaching fraction, applied solutes were, 10.2 and $204 \mathrm{mg} / 100 \mathrm{~g}$ of soil dry mass respectively, for bean and capsicum when irrigated with water of lower salt concentration, and 484 and 1476 $\mathrm{mg} / 100 \mathrm{~g}$ of soil d. $\mathrm{m}$. when irrigated with water of higher salt concentration; with $20 \%$ leaching fraction, instead, the applied solutes were 11.9 and 228 and 554 and 1595 $\mathrm{mg} / 100 \mathrm{~g}$ of soil dry mass (Figure 1 ), respectively, for the waters of lower and higher salt concentrations.

The amounts of water drained from each pot were 

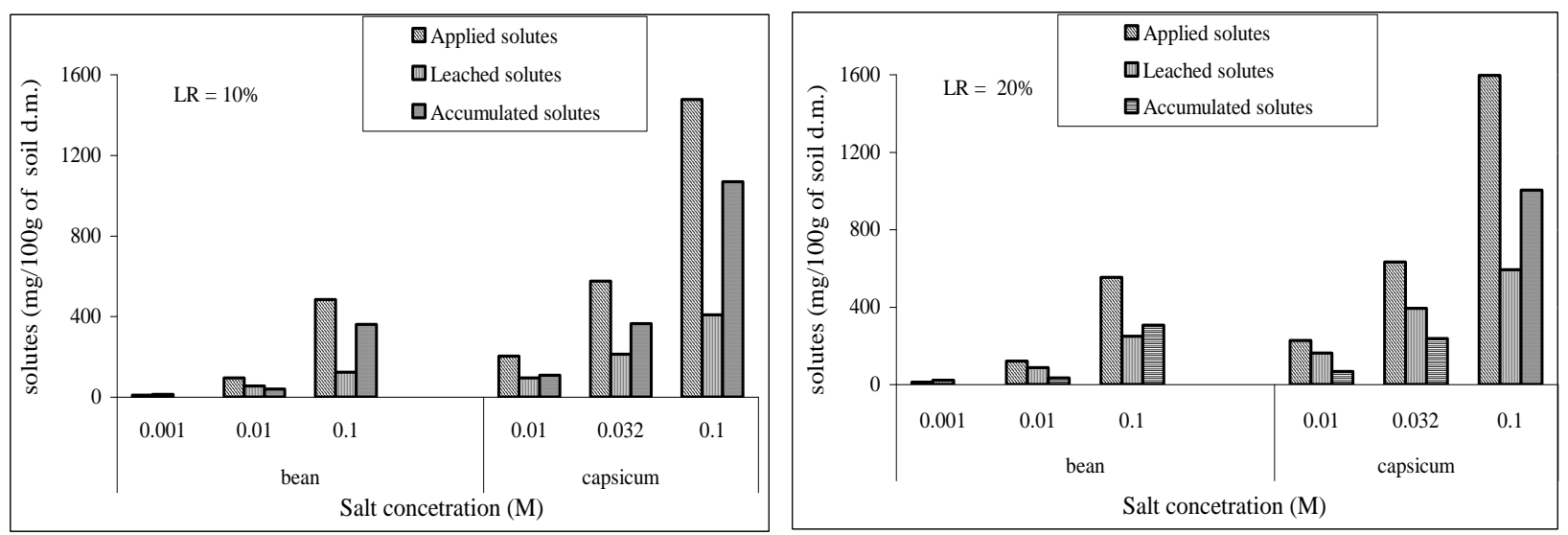

Figure 1. Applied, leached and accumulated solutes in the soil irrigated with water of different salt concentrations and subject to two leaching fractions in t bean and capsicum end of the cropping cycle. For each effect considered, the values followed by the same letter are not significantly different, according to the SNK test at $P \leq 0.01$.

proportional to the applied leaching fractions; the amount of leached solutes, in turn, varied as influenced by the quantity and concentration of drainage water. As a consequence, the leached solutes changed, on average, from the lowest to the highest salt concentration, with LR $=10 \%$, from 14 to $123 \mathrm{mg} / 100 \mathrm{~g}$ of soil dry mass for bean and from 94.5 to $407 \mathrm{mg} / 100 \mathrm{~g}$ of dry mass for capsicum; instead with $\mathrm{LR}=20 \%$, it varied from 21 to $248 \mathrm{mg} / 100 \mathrm{~g}$ of soil dry mass for the crop and from 162 to 592 for the crop (Figure 1). From the balance between applied and leached salts it was found that, irrigating bean with water of lower salt concentration $(0.001 \mathrm{M})$ for both leaching requirements (10 and $20 \%$ of the watering volume), leached solutes were lower than solutes applied through irrigation water; on average, the loss was $6.6 \mathrm{mg} / 100 \mathrm{~g}$ of soil dry mass. For the pots irrigated with water of higher salt concentrations $(0.01$ and $0.1 \mathrm{M}$ for bean and 0.032 and $0,1 \mathrm{M}$ for capsicum), instead, accumulated salts were, on average, 36 and $334 \mathrm{mg} / 100 \mathrm{~g}$ of soil dry mass after bean and 300 and $1035 \mathrm{mg} / 100 \mathrm{~g}$ of soil dry mass after capsicum (Figure 1). In both years, no marked differences were observed in terms of amounts of leached solutes varying the leaching fraction from 10 to $20 \%$ of the watering volume. As a result of the salt balance, the EC values of the saturation of the top layer soil, $30 \mathrm{~cm}$ deep, extract at the end of the 1st and 2nd irrigation seasons respectively, increased, on average, from 1 and $2.2 \mathrm{dS} \cdot \mathrm{m}^{-1}$ for the soils irrigated with water of lower salinity level to 2.1 and $4.3 \mathrm{dS} \mathrm{m}^{-1}$ and to 13.9 and $19.5 \mathrm{dS} \mathrm{m}^{-1}$ for the soils irrigated with waters of intermediate and higher salt concentrations (Figure 2).

With the different SAR values of irrigation water (5 - 15 - 45), the electrical conductivity of the saturation extract (ECe) varied respectively from 5.9 to 5.5 and $4.2 \mathrm{dS} \cdot \mathrm{m}^{-1}$ in the 1st year, and from 8.7 to 8.4 and 7.9 in the 2 nd year (Figure 2).

Slight modifications were, instead, recorded for the $\mathrm{pH}$ of the soil saturation extract, which ranged between 7.4 and 8.1, respectively, using waters of increasing salinity levels and SAR (Figure 3).

With the increase in irrigation water salt concentration, the exchangeable $\mathrm{Na}$ gradually increased whereas the exchangeable $\mathrm{K}, \mathrm{Ca}$ and $\mathrm{Mg}$ did not vary significantly, as shown in Figure 4

With the increase in the SAR of irrigation water, the exchangeable $\mathrm{Na}$ and, to a lower extent, the exchangeable $\mathrm{Mg}$ increased, whereas the amounts of exchangeable $\mathrm{K}$ did not vary significantly (Figure 5).

As a result, the exchangeable sodium percentage increased with the increase in the salt concentration and SAR of irrigation water (Figure 6). The SAR of the soil saturation extract was closely correlated with the exchangeable sodium percentage.

Specifically, exchangeable sodium percentage (ESP), as average of the whole soil profile, consistently increased to the increase of the salinity of the water used and, in any case, to the raise of the SAR value. Increasing ESP values worsen soil structure; in the red soil (T2), rich in organic matter, soil structure remains more stable (stability index $=38.8 \%$ ); this behavior is not observed in the gray calcareous soil (T1) (stability index = $38.8 \%$ ) (Figure 7).

Illite and caolinite play an important role in stabilizing soil structure especially in soils rich in sesquioxides (Cavazza et al., 2002). In both soils, to the increase of salt concentration of the irrigation water, the trend of the soil aggregates stability indices reflected the ESP level. The structural aggregates stability index decreased on average of more than $12 \%$ passing from soils previously irrigated with water having a salt concentration of $0.01 \mathrm{M}$ to those irrigated with water characterized by a salt concentration of $0.1 \mathrm{M}$ (Figure 7). To the low structural stability of not pretreated samples corresponded a higher stability after alcohol pretreatment (Figure 7). The first result represents the conditions at soil surface (effect of rain), while the second better indicates the effect under 

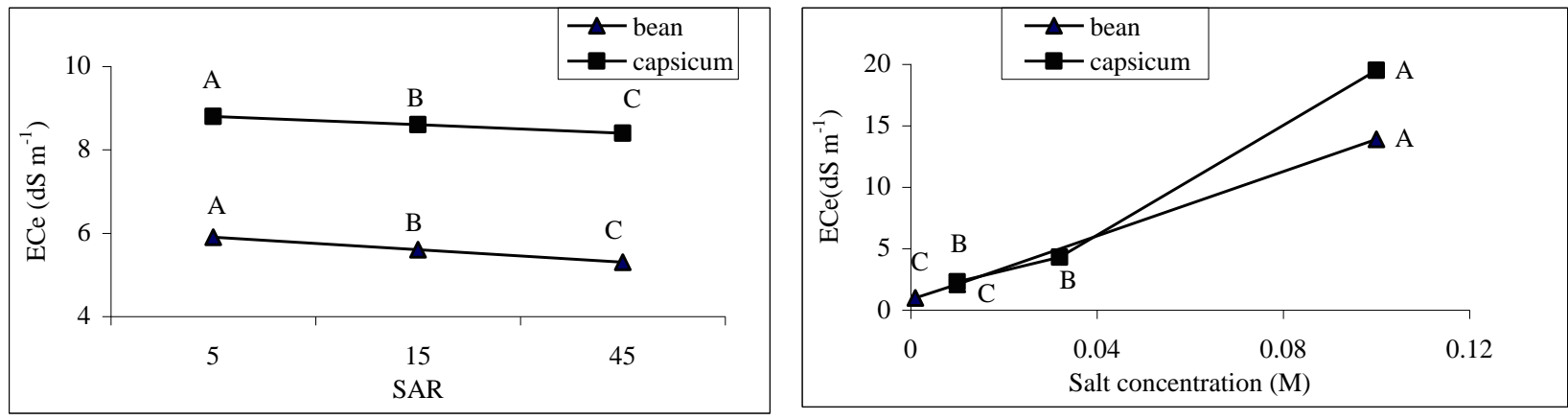

Figure 2. Electrical conductivity of the saturation extract $(E C e)$ of the layer soil, $30 \mathrm{~cm}$ deep, versus the salt concentration and sodium adsorption ratio (SAR) of the solutions used for irrigation in bean and capsicum end of the cropping cycle. For each effect considered, the values followed by the same letter are not significantly different, according to the SNK test at P $\leq$ 0.01 .
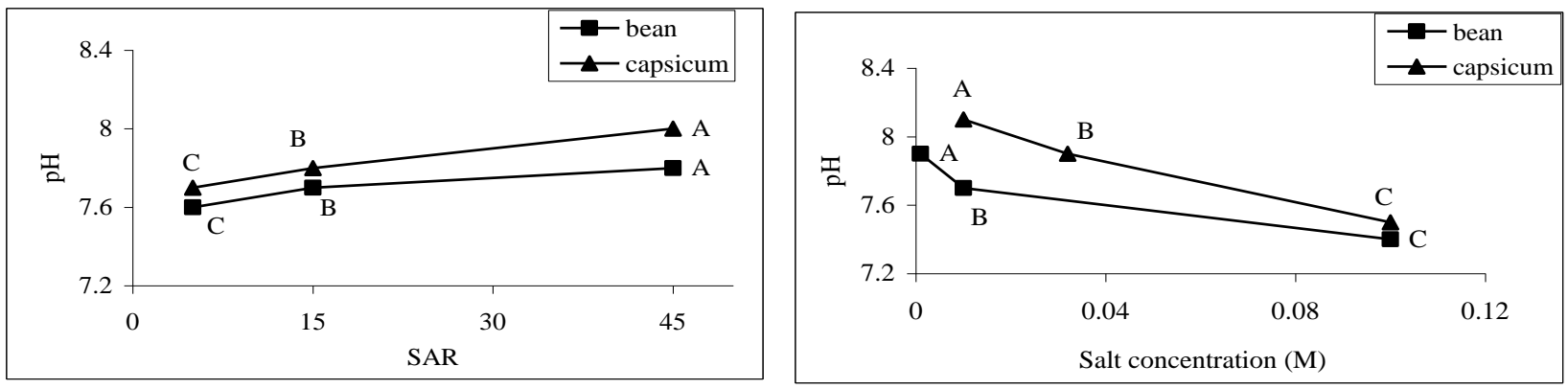

Figure 3. $\mathrm{pH}$ of the saturation extract of the layer soil, $30 \mathrm{~cm}$ deep, versus the salt concentration and the SAR of the solutions used for irrigation in bean and capsicum end of the cropping cycle. For each effect considered, the values followed by the same letter are not significantly different, according to the SNK test at $P \leq 0.01$.


Figure 4. Variations of the soil exchangeable bases versus the concentration of the solutions used for irrigation in bean and capsicum end of the cropping cycle. For each effect considered, the values followed by the same letter are not significantly different, according to the SNK test at $\mathrm{P} \leq 0.01$. 

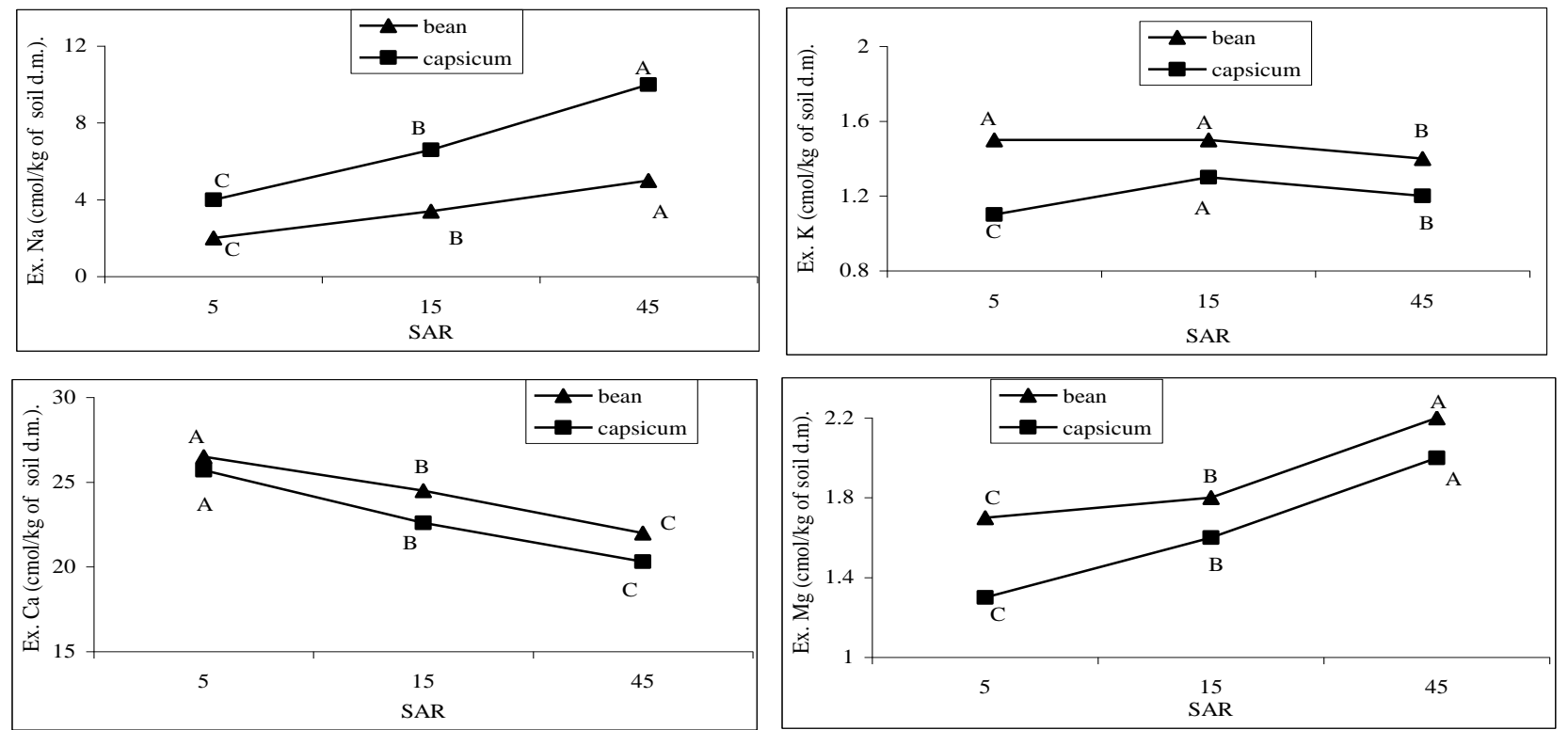

Figure 5. Variations of the soil exchangeable bases versus the SAR (Sodium Adsorption Ratio) of the solutions used for irrigation in bean and capsicum end of the cropping cycle. For each effect considered, the values followed by the same letter are not significantly different, according to the SNK test at $P \leq 0.01$.
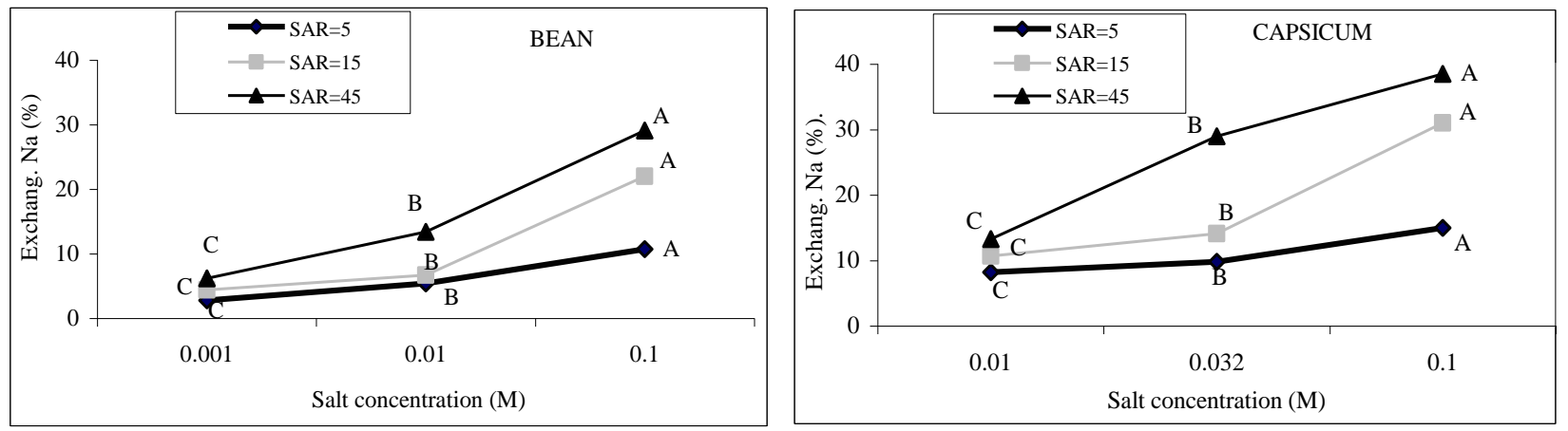

Figure 6. Soil exchangeable sodium percentage (ESP) as influenced by the salt concentration and the SAR (Sodium Adsorption Ratio) of the solutions used for irrigation in bean and capsicum end of the cropping cycle. For each effect considered, the values followed by the same letter are not significantly different, according to the SNK test at $P \leq 0.01$.
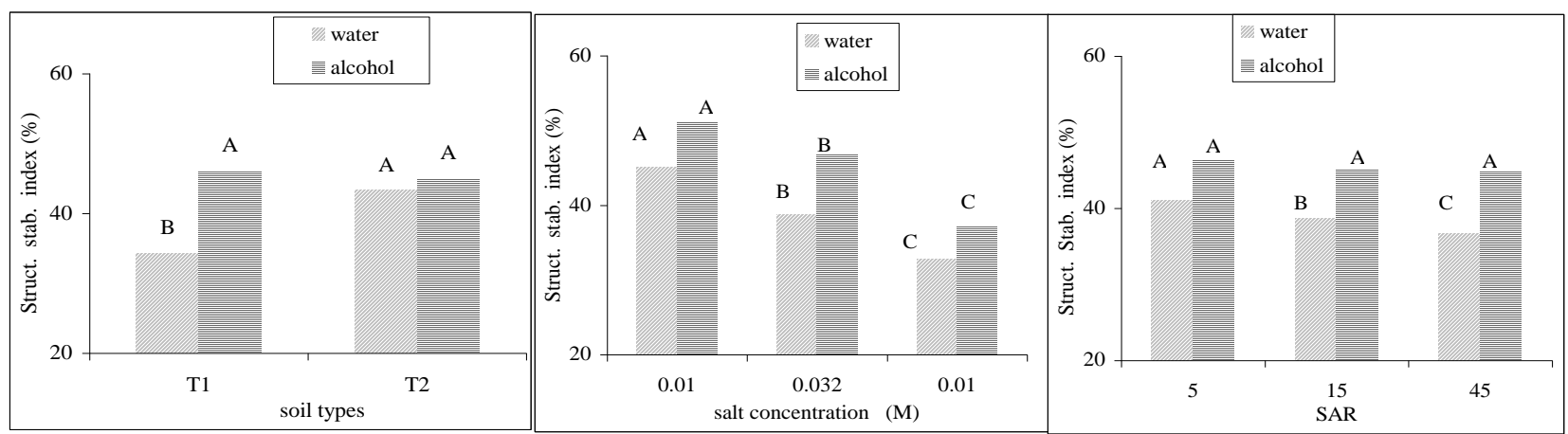

Figure 7. Variation of the soil aggregate stability index, with or without alcohol pretreatment as function of soil type, salt concentration and irrigation water SAR. For each effect considered, the values followed by the same letter are not significantly different, according to the SNK test at $P \leq 0.01$. 
the soil surface (Cavazza et al., 2002).

\section{DISCUSSION}

A two-year research was conducted on two soil types, packed in cylindrical pots located under shed, in which bean and capsicum were grown in succession and irrigated with nine types of water, with different salt concentrations and SAR values, and subject to two different leaching requirement levels. The following conclusions may be drawn: The seasonal irrigation volume increased when the leaching requirement (LR) was doubled from 10 to $20 \%$ of the watering volume; it decreased, instead, as the salinity of the irrigation water increased. This is due to the fact that salts induced less crop growth and reduced evapotranspiration.

The soil applied solutes increased proportionately to the applied water volume and its salinity. The drainage water volumes were different in relation to the applied leaching requirements. In the first year, because of the soil pore-size reduction, due to soil compaction, and water salinity, drainage water volumes were low, when low and medium salinity waters were used; they were higher, instead, when higher salinity water was used. In the second year, when the salt concentrations of low and medium salinity waters were higher than those of the first year, the drainage water volumes were higher as compared to the applied leaching requirement. The amounts of leached solutes varied with the amount and salt concentration of drainage water. However, with the same amounts of leaching requirements, the leached solute percentage, as compared to those supplied with irrigation water, decreased considerably as the irrigation water salinity increased, with a subsequent reduction of the leaching efficiency of applied water. Therefore, the amount of solutes accumulated in the soil increased as the salt concentration of irrigation water increased; on the other hand, there was a slight variation with the higher leaching requirement and between the two compared soils. The results show that in the Mediterranean areas, where the long-term average yearly rainfall is not less than 450 to $500 \mathrm{~mm}$, winter rainfall could effectively leach the solutes applied with saline water, thus reducing the amounts of irrigation water and the solutes applied to the soil.

As a result of the balance between applied and leached solutes, at the end of the irrigation season of the first and second years, the electrical conductivity of saturation extract (ECe) of the $0.3 \mathrm{~m}$ top soil layer, irrigated with the lowest and the highest saline waters, resulted, respectively, equal to 1 and $2.2 \mathrm{dSm}^{-1}$ and to 13.9 and $19.5 \mathrm{dSm}^{-1}$, against an average value of $0.71 \mathrm{dS} \mathrm{m}^{-1}$ recorded before starting the research. As to the characteristics of the saturation extract by increasing the salt concentration of irrigation water, the $\mathrm{pH}$ decreased slightly, while by increasing the SAR, the ECe varied a little and the $\mathrm{pH}$ increased. The exchangeable sodium percentage (ESP) increased gradually while the exchangeable calcium percentages decreased gradually as the increasing salinity and SAR of irrigation water increased. The exchangeable potassium percentage did not vary appreciably, and the exchangeable magnesium percentage increased with the rise of the irrigation water SAR.

Soil structure stability index progressively decreased to the increase in soil salinization and sodication in the two soil types. In the red Locorotondo soil, with the clay fraction rich in illite and caolinite, and also in organic matter and iron and aluminum oxides, the structure aggregates remained more stable.

\section{ACKNOWLEDGEMENTS}

This work is part of the co-operative research programme n. 9807038430 co-financed by the Ministero dell'Università e della Ricerca Scientifica e Tecnologica and the University of Bari.

\section{REFERENCES}

Ayers RS, Westcot DW (1985). Water quality for agriculture. Irrigation and Drainage. Paper No 29, FAO, p. 174.

Bresler E, MacNeal BL, Carter DL (1982). Saline a nd sodic soils: PrinciplesDynamics-Modeling.

Berlin/Heidelberg/New York. p. 236.

Cavazza L, Patruno A, Cirillo E (2002). Soil trait and structure stability in artificial sodicated soil. Italian J. Agron. 6(1):15-25.

Corwin DL, Rhoades JD, Simunek J (2007). Leaching requirement for soil salinity control: steady-state versus transient models. Agric. Water Manage. 90:165-180.

Graifenberg A, Lipucci Di Paola M, Giustiniani L (1993). Yield and growth of globe artichoke under saline-sodic conditions. HortSci, 8:791-793.

Halliwell DJ, Barlow KM, Nash DM (2001). A review of the effects of wastewater sodium on soil physical properties and their implications for irrigation systems. Australian J. Soil Res. CSIRO publishing 39:1259-1267.

Hénin S, Gras R, Monnier G (1969). Le profile cultural. Masson et Cie, Paris. p.332.

Howell TA (1988). Irrigation Efficiencies: Handbook of Engineering in Agriculture. CRC Press, Boca Raton, Florida. pp.173-184.

Kemper WD, Rosenau RC (1986). Aggregate stability and size distribution. In: Klute A. (ed.): Methods of Soil Analysis. Parti. Physical and mineralogical methods. Agronomy 9:425-442. ASA and SSSA, Madison, WI, USA.

Levy GJ, Van der Watt HVH, Shainberg I, Du Plessis HM (1988). Potassium-calcium and sodium-calcium exchange on kaolinite and Kaolinitic soils. Soil Sci. Soc. Am. J. 52:1259-1264.

Manachini B, Corsini A, Bocchi S (2009). Soil quality indicator as affected by a long term barley-maize an cropping systems. Italian $\mathrm{J}$. Agron. 1(15):15-22.

Minhas PS, Dubey SK, Sharma DR (2007). Comparative affects of blending, intera/inter-seasonal cyclic uses of alkali and good quality waters on soil properties and yields of paddy and wheat. Agric. Water Manage. 87:83-90.

Murray RS, Quirk JP (1990). Interparticle force in relation to the stability aggregates. In M.F. De Boodt, M.H.B. Hayes, A. Herbillon, Editors, Soil colloids and their Associations in aggregates, Plenum Press, New York. pp. 439-461.

Pasternak D, De Malach Y (1987). Saline water irrigation in the Negev desert. Conference on Agriculture and Food Production in the Middle East. Athens, Greece, January 21-26, p. 24. 
Postel S (1996). Forging a sustainable water strategy. In: State of the world 1996. Ed.: Brown R.L., London. pp. 40-59.

Postiglione L, Barbieri G, Tedeschi A (1994). Long-term effects of irrigation with saline water on some characteristics of a clay loam soil. ESSC Conference on Problems and Management of soil salinizationalkalinization in Europe. Budapest, 26-30 April.

Richards LA, Allison LE, Bernstein L, Bower CA, Brown JW, Fireman M, Hatcher JT, Hayward HE, Pearson GA, Reeve RC, Wilcox LV (1954). Diagnosis and Improvement of Saline and Alkali Soils. U.S. Dept.

Agr. Handbook p. 60, U.S. Govt. Printing Office, Washington D.C. p. 160.

So HB, Aylmore LAG (1993). How d o sodic soils behaved the effects of sodicity on soil behavior. Australian J. Soil Res. 31:761-778.

Szabolcs I (1989). Salt Affected Soils. CRC Press Inc, Boca Raton, Florida. p. 274.
Tedeschi A, Dell'Aquila R (2005). Effects of irrigation with saline waters, at different concentrations, on soil physical and chemical characteristics. Agric. Water Manage 77:308-322.

Tedeschi A, Menenti M (2002). Simulation studies of long-term saline water use: model validation and evaluation of schedules. Agric. Water Manage. 54:123-157.

UNESCO (2003). World Water Development Report. Water for People, Water for Life. UNESCO Publishing, Barghahn Books.

van der Zee SEATM, Shah SHH, van Uffelen CGRPAC, Raats dal Ferro N (2010). Soil sodicity as a result of periodic al drought. Agric. Water Manage. 97:41-49. 